\title{
Decentralization in Africa and the Resilience of Traditional Authorities: Evaluating Zimbabwe's Track Record
}

\section{Tinashe Carlton Chigwata}

To cite this article: Tinashe Carlton Chigwata (2015) Decentralization in Africa and the Resilience of Traditional Authorities: Evaluating Zimbabwe's Track Record, Regional \& Federal Studies, 25:5, 439-453, DOI: $10.1080 / 13597566.2015 .1121873$

To link to this article: https://doi.org/10.1080/13597566.2015.1121873

Published online: 09 Dec 2015.

Submit your article to this journal $\square$

Џلll Article views: 891

View Crossmark data $\complement$

Citing articles: 7 View citing articles ๘ 


\title{
Decentralization in Africa and the Resilience of Traditional Authorities: Evaluating Zimbabwe's Track Record
}

\author{
TINASHE CARLTON CHIGWATA
}

\author{
Multi-level Government Initiative, Dullah Omar Institute for Constitutional Law, Governance and \\ Human Rights, University of the Western Cape, Bellville, South Africa
}

\begin{abstract}
This paper looks at one of the most important endogenous factors influencing the workings of decentralization in Zimbabwe. Successive waves of formal institutional change that took place during Zimbabwe's colonial and post-colonial history have been unable able to uproot the influence of traditional leaders. Due to their home-grown legitimacy, various traditional authorities continue to play an ever-present role in the lives of people in rural areas. But, as it is the case throughout most of Africa, the powers of traditional leaders have mostly been uncodified under modern law and these power relations tend to be rather informal and culturally inaccessible to most outsiders. Consequently, the scholarly literature has not been able to systematically acknowledge their pervasive influence. The article concludes with a reflection on how the influence of traditional authorities can be translated into the democratic and progressive empowerment of rural populations in the developing world.
\end{abstract}

KEY WoRDs: Decentralization, traditional authorities, rural politics, social legitimacy, Zimbabwe, Africa

\section{Introduction}

Throughout the African continent, the 1990s witnessed large-scale political reforms introducing decentralization (Fessha and Kirkby, 2008; Erk, 2014). Most such reforms aimed to bring in better democracy and better policy performance through creating and strengthening the local government level. In the quest to bring in instant solutions, most emphasis was on institutionally engineering best practices, often based on the prevailing ideas among the experts of development studies community. Yet, as this special issue shows, despite the similarities in institutional design, the results of these reforms vary significantly across African countries, and such variation suggests that endogenous factors play a role (see especially, Krol, 2015). That is, home-grown local factors seem to influence the workings of decentralization, 
running parallel to the mostly exogenous institutional designs. In many of the countries that have undergone institutional reforms, the influence of traditional authorities at the local level has been a common endogenous factor influencing decentralization; or more precisely, influencing local government performance. But since the powers of traditional leaders have mostly been uncodified under modern law and since these power relations tend to be rather informal and culturally inaccessible to most outsiders, the development studies literature has not been able to systematically acknowledge the pervasiveness and influence of traditional authorities. Furthermore, across the different cultures and ethnicities of Africa, traditional authorities differ-some being more hierarchical and hereditary, while others more egalitarian and elective. But one thing is common: due to their home-grown legitimacy and deep roots, these various traditional authorities play a pervasive and ever-present role in the lives of people in rural areas, often far more than the seemingly distant modern state, its bureaucrats and politicians.

The decentralization reforms of the 1990s was not the first time the African continent had been subjected to the hopes that institutional design alone will deliver. The case of Zimbabwe is an informative case study in this context. Despite being a timeless part of the local fabric, during British South Africa Company (BSAC), British Imperial and Rhodesian phases of colonial rule and the subsequent phase of independence, traditional authorities and leadership were seen as backward relics of pre-modern times holding back progress. Development was equated with the replacement of these in rural areas, which had remained beyond the reach of urbanization and modernization. Consequently, formal institutional design was done without the acknowledgement and recognition of such authorities, nor did the local context come to play any role in the design, fine-tuning and adjustment of reform programmes. After all, these pre-modern relics had to go. The fact that many such authorities condoned and even carried out certain illiberal cultural practices did not win them many friends among the African liberation movements. In many parts of Africa, the progressive politics of post-colonialism was dominated by, what Robert Bates calls an "urban bias" (Bates, 1981). Not only were traditional authorities deemed backward, but historically they also had been co-opted into the system of 'indirect rule' practised by British colonial rule throughout Africa (Crowder, 1964)). In the eyes of those within liberation movements, traditional leaders had become the outsourced arm of colonial authorities and collaborators. This often meant that during the first phase of post-colonialism, traditional leaders and authorities had few friends among the new generation of African leaders. Furthermore, many elected political leaders in the newly independent states viewed the existence of traditional authorities as a direct competition for legitimacy, leadership and support. Yet, traditional authorities did not wither away as a result of development and modernization.

Zimbabwe has undergone various phases of institutional reform during colonial and post-colonial times either co-opting, distorting or denying the presence of traditional authorities, but somehow none of these institutional engineering episodes managed to uproot them. What in fact happened is successive waves of political institutions designed and put in place during these reforms withered away. Zimbabwe's traditional authorities are still there and they continue to play a big role in the daily lives of rural populations. They have many weaknesses: many are strictly hierarchical and have archaic views on women's rights; they are often materially dependent on the 
centre and thus still prone to be co-opted by the central government; but nonetheless, they continue to command significant respect, support and legitimacy. Wishing them away did not work; acknowledging, reforming and incorporating them into formal local political institutions might be a more realistic way to build functioning democratic local politics.

One common culprit in the failure of decentralization reforms to deliver on their promises is the deficiencies in what is known as "state capacity" (Bratton and Chang, 2006). Many newly created local governments throughout Africa have had difficulties in getting things done in their newly assigned policy competences. But the notion of state capacity should not be limited to material deficiencies in infrastructure, trained and qualified personnel, and scarce resources. Put simply, local autonomy-no matter how limited-will remain vacuous if the local is not in it. The notion of state capacity could easily be expanded to include these local embodiments of collective action and public spirit which have deep roots and enjoy home-grown legitimacy. No matter how perfect institutional reform packages appear on paper, their capacity to deliver is closely related to the question of whether they enjoy legitimacy in the eyes of the rural populations. Instead of being seen as alien institutions imposed from the centre or from abroad, traditional authorities are seen as part of the local fabric. Building capable states in Africa therefore will likely require, among other actions, integrating traditional institutions of governance with those of the modern state.

The article seeks to expose how resilient traditional authorities have been throughout Zimbabwe's history and explores the reasons for their longevity. The first step in this direction is the examination of the sociopolitical context within which both traditional authorities and modern state structures have operated. This is followed by an overview of decentralization in general and its promises. The discussion of the Zimbabwean case is then located within the broader decentralization debate. This section examines the shifting political attitudes towards traditional authorities in Zimbabwe during pre-colonial, colonial and post-colonial periods. The article concludes with a reflection on how the influence of traditional authorities can be translated into the democratic and progressive empowerment of rural populations.

\section{Sociopolitical Background}

Traditional authorities have always had a role to play in region that eventually came to be known Zimbabwe. The Republic of Zimbabwe is located in Southern Africa, where it borders Mozambique to the east, Zambia to the north, Namibia to the north-west, Botswana to the south-west and South Africa to the south. The country is divided into 10 provinces, namely Mashonaland Central, Mashonaland East, Mashonaland West, Matabeleland North, Matabeleland South, Midlands, Masvingo, Manicaland, Harare and Bulawayo. Zimbabwe is home to the descendants of various (Ma)Shona tribes, the Ndebele ethnic group and other small ethnic groups such as Kalanga and Tonga. It is also home to a small group of Indian descent, coloureds and white Africans. The Census of 2012 estimated the total population of Zimbabwe to be just over 13 million of which $99.7 \%$ are of African origin while only $0.3 \%$ is from European, Asiatic and mixed origin (Zimstat, 2012: 13, 26). The majority of this 13 
million resides in rural areas where traditional leaders are the immediate form of local governance. For over a decade, Zimbabwe had been experiencing deep political and economic challenges. In a bid to arrest some of these challenges, Zimbabwe adopted a new Constitution in 2013.

The 2013 Constitution provides for a unitary form of government but with government organized at three levels. At the national level, there is the national government while the middle tier of government is made up of provincial and metropolitan councils. Urban and rural local authorities (local governments) make up the lowest tier of government with the former administering urban areas while the latter administers rural areas. Rural areas are administered by rural local authorities alongside the institution of traditional leadership comprising chiefs, headmen and village heads (names and organization vary across Africa). There are about 272 chiefs, 452 headmen and 25,000 village heads (Musekiwa, 2012: 240-242). The village is the lowest administrative structure in rural areas of Zimbabwe led by a village head. The village head reports to a headman who is in charge of several villages. The headman then reports to the chief.

Chiefs are appointed by the president whereas headmen are appointed by the minister responsible for traditional affairs upon the recommendation of the relevant chief. Village heads are appointed by the national government secretary responsible for traditional affairs upon the recommendation of the relevant headmen with the approval of the chief of the area. It is important to note that the titles of chief, headman and village head are hereditary, thus cannot be given arbitrarily. This means that while the government may have the power to appoint traditional leaders, it is not at liberty to appoint anyone to the position of chief, headman or village head because of custom and tradition. The 2013 system of local government is remarkable in the sense that traditional authorities have been fully acknowledged, recognized and incorporated into the Constitution in formal terms. Until then (bar the 1998 Traditional Leaders Act), successive institutional set-ups throughout Zimbabwean history had tried to circumvent their existence or limit their role and influence-something the last phase of reform bringing decentralization to rural areas could no longer do.

\section{The Promises of Decentralization}

Decentralization is often associated with a number of benefits including its potential to promote development, democracy and peace. Most countries have heterogeneous communities with distinct preferences for local public goods and services. Local governments may promote local distribution of public services that closely match local preferences because they are physically closer to the citizens than the central government. The argument is that the provision of public services closely matching local preferences is likely to result in higher levels of efficiency than would occur under a centralized system of government (Bardhan and Mookherjee, 2006: 6). A centralized system of government is unlikely to implement several and varying policies across the country. This limits the possibilities to acknowledge and incorporate local preferences. In contrast, a decentralized system of government can encourage experimentation and innovation as individual jurisdictions are largely free to try new approaches to public policy (De Visser, 2005: 24). The advantage of decentralizing 
policy choices to local governments is that several different policies can be considered simultaneously, in the process uncovering new ways to accelerate the realization of development goals; or as the introduction to this special issue puts it, "turning local governments into laboratories of policy-making and implementation" (Erk, 2015).

On the democratic front, decentralization has potential to widen opportunities for political participation at local levels (Andrew and Goldsmith, 1998: 107). In a democratic state all public officials, whether elected or appointed, as well as bodies exercising public authority, are accountable to citizens. And when government is physically closer to the people as is the case under a decentralized system of government, public officials are more likely to be easily held accountable. Decentralization also creates vertical checks and balances that can constrain the central and local governments' attempts to overstep their powers. A decentralized system of government thus constitutes a specific and extended expression of the basic principle of separation of powers, which strengthens the accountability of one level of government to another (Pandey, 2005: 12).

Besides its potential to promote development and deepen democracy, decentralization has the potential to build and sustain peace in a number of ways. For example, a decentralized system of government provides opportunities for geographically concentrated minority groups, which are unlikely to influence politics at national level, to exercise a degree of political authority in local and regional jurisdictions (Jackson and Scott, 2008: 5). Self-rule allows distinct groups to exercise some degree of autonomy, which reduces intergroup strife in ethnically diverse societies (Siegle and O’Mahony, 2010: 135). The self-rule offered to minorities at subnational level can enhance national cohesion and may undermine feelings of neglect among minority ethnic groups - which is one of the causes for violent conflict especially in SubSaharan Africa.

But while the potential exists to promote development, democracy and peace in a number of ways, decentralization has not always delivered on these promises. In some cases, decentralization in fact rendered elusive the achievement of these goals (for example, Argentina in the 1980s and 1990s and parts of present-day Africa). Decentralization also seems to come with the risks of corruption at the local level; economic disparities between various local governments; macroeconomic instability due to badly coordinated economic policies between local, regional and national levels of government; and ethnic polarization at the local level (Erk, 2014: 11-13). So all this seems to suggest that factors other than decentralized institutions themselves must account for the workings of decentralization. The lesson then seems selfevident: when designing decentralization programmes, it is crucial to include an adequate consideration of the contextual political, economic and social environment. As the introduction to this special issue argues, we might otherwise end up with "iron houses in the tropical heat" (Erk, 2015). Questions of this nature which seek responsive crafting of policies to the local environment are still relevant to present-day democratic decentralization reforms in Africa. These questions are critical given that traditional authorities exert most influence at the local level particularly in rural areas where they command significant respect, support and legitimacy. This is not confined to Zimbabwe and is the case throughout the African continent (UNECA, 2004). The majority of Africans live in areas that are categorized as rural. In Zimbabwe, for instance, about 
$67 \%$ of the population resides in these areas (Zimstat, 2012: 25). And in rural Africa, traditional authorities still hold sway.

The Afrobarometer surveys carried out between 1999 and 2001 (round 1), and in 2000 (round 2) offer a concrete basis for evaluating the relevance of traditional authorities. The surveys were carried out in 15 African countries (Botswana, Cape Verde, Ghana, Kenya, Lesotho, Malawi, Mozambique, Namibia, Nigeria, Senegal, South Africa, Tanzania, Uganda, Zambia and Zimbabwe). Survey results show that, relative to elected leaders (councillors, members of parliament, the president and other members of the executive), traditional leaders are contacted more frequently by ordinary Africans in their efforts to solve their problems or express their views (Logan, 2008). In these countries, popular perceptions of traditional leaders have been found to be slightly more positive than those for elected leaders. Importantly, the empirical research shows that "the sharp distinctions outsiders draw between elected local government officials and hereditary chiefs are not made by most of the Africans who live under these dual systems of authority" (Logan, 2008: 1). To the contrary, "far from being in competition with elected leaders for the public's regard, traditional leaders and elected leaders are seen by the public as two sides of the same coin" (Logan, 2008: 1).

There are also signs that traditional authorities have been able adapt to changing times. For instance, in South Africa, the Royal Bafokeng Community installed a wide-area internet for use by local institutions in 2000. The Bafokeng Tribal Court adjudicates cases under the supervision of a qualified attorney at law (UNECA, 2004: 41). The United Nations Economic Commission for Africa also reports the successful track record of traditional leaders in conflict resolution throughout Africa (See UNECA, 2004). Many traditional authorities in Africa have embraced the grassroots democratic practices of citizen consultation and participation. Increasingly, women are selected and appointed as traditional leaders - a development which was considered taboo in many traditional cultures not long ago. Since 1980, no fewer than five women have been appointed as chiefs in Zimbabwe, while several others have been appointed as headperson and village heads (See Obediah, 2013: 36). In tandem, many individuals of a younger and educated background are being selected and appointed as chiefs in Zimbabwe and other African countries (Obediah, 2013: 36).

And once we expand the notion of 'state capacity', as discussed earlier, to include non-material factors beyond infrastructure, personnel and resources, the importance of traditional authorities becomes apparent. Most governments in Africa lack capacity to deliver public services to their citizens, especially those in the remote parts of the country. Without the support of traditional leaders it is difficult for the modern state to mobilize the support of rural populations. Traditional leaders can use their position, power and influence to ensure cooperation (see Makahamadze et al., 2009). For instance, in some parts of Mashonaland Province in Zimbabwe, the erection of telecommunication infrastructure in areas considered sacred (like mountains) was heavily resisted by the local people despite the good intentions of the government and private actors to provide modern telecommunication mechanisms in rural areas. The erection was only permitted following the intervention of traditional leaders.

Traditional authorities also help with policy coordination issues. Chakaipa (2010: 53) states that traditional leaders remain an effective tool of communication in 
Zimbabwe's rural areas due to the hierarchical organization of traditional authority: chiefs, headmen and village heads. But most importantly, throughout Africa traditional authorities often provide continuity and stability in times of rapid change and development. In fact, these traditional institutions provide a very modern role: they make change appear familiar. It is difficult to imagine how a decentralization programme can be successful without providing for the role of traditional authorities-especially considering how resilient they have proven to be throughout the various political episodes of Zimbabwean history.

\section{The Resilience of Traditional Authorities in Zimbabwe}

\section{The Pre-Colonial Period}

Colonial rule in Zimbabwe (formerly Rhodesia, and Southern Rhodesia before that), like elsewhere in Africa, distorted traditional systems of governance through war and imposed a repressive modern administration on the indigenous people (Keulder, 1998: 201). Before colonization, traditional systems of governance of kings, chiefs, headmen and village heads were the only governance structures with legitimacy to govern. In Zimbabwe, there were two dominant political entities prior to the arrival of the Europeans; namely the Ndebele and (Ma)Shona kingdoms. The Shona Kingdom was politically organized in relatively autonomous chiefdoms, which were usually subdivided into wards made up of several villages. Chiefs followed traditional consultative and deliberative 'democracy' when governing their chiefdoms. For example, before making any decisions, chiefs consulted their council machinery comprising advisers, councillors, ward and village headmen, and senior family members (Makahamadze et al., 2009). Wards, under the leadership of a headman, had significant autonomy including power over land. The headman was assisted by an informal council comprising village headmen and some senior kinsmen. Village headmen referred serious issues to the ward headman who could also refer issues to the chief for consideration. Thus, the Shona Kingdom functioned on a decentralized framework. While chiefs, headmen and village heads provided political guidance, spirit mediums provided spiritual governance. This nature of traditional governance system has remained largely intact to the present day, existing parallel to the modern state structures but without 'adequate' formal recognition.

The Ndebele Kingdom in the south-western areas of present-day Zimbabwe, unlike its Shona counterparts, operated on a highly centralized governance structure. The king was the highest decision-making authority, exercising all governmental powers including total control over cattle and land. He was assisted by some advisers who comprised headmen and representatives of the royalty. The kingdom's political centre was the city of Bulawayo, but there were also provinces, each under the control of a 'great' chief. These provinces were further divided into regiments under the leadership of a chief. Wards which were governed by headmen comprised a regiment. The headmen were at the lowest level of the judicial system. Like in the (Ma) Shona kingdoms, a headman could refer serious cases to the regiment chief. The regiment chief could also refer them to the 'great' chief from where they might be referred to the king (Keulder, 1998: 145). The Ndebele Kingdom was militarily more advanced than the 
Shonas. It was therefore not a surprise that the kingdom provided strong military resistance to intrusion by the BSAC, which entered the territory of present-day Zimbabwe under the leadership of Sir Cecil John Rhodes in the late nineteenth century. After the colonization wars of the $1890 \mathrm{~s}$, traditional structures of governance were dismantled and replaced by modern structures imposed by BSAC. This marked the beginning of formal institutional changes which threatened the very existence of traditional authorities in Zimbabwe for more than a century.

\section{Colonial Period}

Zimbabwe was under colonial rule for a century (1890-1980). Colonization had begun when the BSAC, with the permission of the British government, occupied the land now referred to as Zimbabwe. But this was only after the military resistance of the Ndebele Kingdom was broken. The company first undermined and then dismantled the traditional governance structures of the Ndebele, as well as the neighbouring Shona kingdoms and replaced these with new national and local institutions (Keulder, 1998: 201). Even though modern local structures were created, the colonial government had to rely informally on traditional leaders for the governance of communal areas where the majority of the black African population resided. Due to the effective and organized resistance of the Ndebele Kingdom to the advance of the BSAC, the British colonial practice of indirect rule, as was the case in East and West Africa, was not fully followed in Zimbabwe. Colonial rule was more heavy-handed and European settlement in the territory was encouraged. Black Africans were driven to reserves or Tribal Trust Lands under various colonial Acts and policies. The BSAC sought measures to weaken the institution of traditional leadership and pervert traditional authority to advance its interests. In 1898, native affairs were placed under the Natives' Department with native commissioners given all political powers over native affairs including the power to appoint chiefs and the amalgamation of tribes. The commissioners assumed most of the responsibilities which were undertaken by chiefs prior to colonization including the allocation of land, the issuing of cattle permits, the regulation of native settlements and judicial role (See Makahamadze et al., 2009).

The most significant change was that chiefs began to be appointed as salaried government officials answerable to the colonial government for the conduct of their communities. Keulder (1998: 149) states that from this period the term of office of a chief depended on "good behaviour and fitness". Headmen were appointed by the Secretary for Native Affairs upon the recommendation of the relevant chief. It was a crime for a chief to appoint a headman without the approval of the native commissioner. So this was not a system of indirect rule where British power was exercised through collaboration with exiting emirates, princedoms and kingdoms (Crowder, 1964). In Zimbabwe traditional leaders were directly enlisted as British colonial officers. And they lacked the (limited) autonomy that traditional leaders in other British colonies enjoyed. For instance, in 1917, Chief Makoni of Rusape in Manicaland Province was reprimanded for appointing and installing a headman without the approval of the commissioner (Makahamadze, 2009: 38). Below the headmen were "book heads" (now village heads) who were no longer appointed according to custom (Keulder, 1998: 149). The introduction of salaries and administrative methods of 
appointing traditional leaders compromised the grassroots legitimacy of this timeless institution. Customary ways of appointment of traditional leaders and hereditary principles of succession were significantly distorted in some places. The institution of traditional leadership was further weakened by new reserve boundaries that did not took cognizance of existing tribal boundaries. As a consequence, some chiefs found their subjects falling under the jurisdiction of others.

BSAC rule lasted until 1923 when the territory, now renamed Southern Rhodesia, was declared a British colony with self-government (which meant white-minority rule). The institution of traditional leadership continued to play an uncodified role in rural governance despite formal changes in the nature of government. But the dominant attitude towards traditional leaders continued to be negative; they were perceived to be uneducated, conservative, tradition-bound and only useful for peacekeeping. Furthermore, traditional leaders were considered to be incapable of promoting progressive policies relating to modernization of agricultural practices and development in general. Like its BASC predecessor, the Southern Rhodesian government continued with the policy of weakening the institution of traditional leadership and increasing grip over the institution. Traditional tribes were further amalgamated, the number of traditional leaders was reduced, and chiefs and headmen continued to be government-appointed and salaried officials. But once again, the uncodified structures behind the institutional façade showed its resilience. It soon became clear that new policies could not be implemented without the assistance of traditional leaders. The government then sought measures to 'reinvent' the very traditions and customs it had tried to destroy. Legislative reforms restored some of the powers of traditional leaders. The African Affairs Act of 1927 gave chiefs the power to chair the Tribal Land Authorities which controlled the use and occupation of tribal (communal) land. The Act also gave back to traditional leaders (limited) criminal jurisdiction and power to solve disputes between black Africans as well as to collect taxes on behalf of the colonial government (Marsh et al., 1974: 229). In 1937, the status of chiefs and headmen was improved as they were made ex officio members of the newly created African Councils (local government structures) in communal areas (Palley, 1966: 660).

In 1954 Southern Rhodesia joined Northern Rhodesia (now Zambia) and Nyasaland (now Malawi) to form the Federation of Rhodesia-Nyasaland. The new federal government also relied heavily on traditional leaders for the implementation of its policies and legislation in communal areas. When the federation broke up in 1963, Southern Rhodesia reverted to its status as a British colony before declaring itself an independent state in a proclamation commonly known as the Unilateral Declaration of Independence (UDI) of 1965. After the UDI, the white-minority rule of Rhodesian government increasingly involved the traditional authorities in national politics and relied significantly on them to implement its policies and thwart growing African nationalism (Jordan, 1983: 10). The regime used 'carrot and stick' methods to garner support from traditional leaders, but even the 'carrot' policies showed little respect for native culture, traditions and customs in the amalgamation of tribes and appointment of traditional leaders. Palley (1966: 476) points out that as of 1964 almost half the Shona chiefs were not the proper heirs to the position after the 
amalgamations. Traditional leaders who were reluctant to implement colonial policies were removed from their positions and those who were sympathetic to the government were rewarded. For instance, Chief Makiwa Nyashanu lost his position as a chief after refusing to implement the colonial 'reserves' policy (Makahamadze et al., 2009). Under the policy, black rural Africans were to be restricted in certain areas known as reserves as a way of curbing support to liberation war fighters. The status of chiefs was constantly improved as black African resistance against minority rule intensified (see De Valk and Wekwete, 1990: 88). Makumbe (1998: 21) argues that the elevation of the status and role of traditional leaders was not only undertaken to thwart African nationalism but also intended by the colonial government as a way of divesting itself of development responsibilities in rural areas. Not surprisingly, by the time of independence in 1980, most who had been part of the liberation movement had lost faith in traditional leaders.

\section{The Post-Colonial Period}

In 1980, the Zimbabwe African National Unity-Patriotic Front (ZANU-PF) came to power. The party followed the ideas of the new generation of post-colonial leaders (Sekou Touré, Kwame Nkrumah and Leopold Senghor), which left no room for traditional authorities in independent democratic Africa-even at the local level. Soon after independence, the ZANU-PF led government declared its intention to promote democratization, national integration and decentralization. A series of legislative enactments and directives were issued to democratize and strengthen the national and local systems of government. The African Councils Act was amended into the District Councils Act in 1980 (and again in 1981 and 1982), establishing district councils governing communal areas. Among other objectives, the Act sought to promote democratic representation and participation and rural development by rationalizing and strengthening the role of the district council as an elected body (De Valk and Wekwete, 1990: 90, Rambanapasi, 1992: 1512).

The first signal of government policy towards traditional leaders was highlighted by the District Councils Act. The Act limited the role of traditional leaders by transferring land allocation and taxing powers from chiefs and headmen to elected district councils. It further stripped the authority of traditional leaders to preside over village civil cases and established a new system of community courts (Mutizwa-Mangiza, 1991: 56, Rambanapasi, 1992: 1512). Chiefs and headmen only retained their ex officio membership of the councils. Second, after independence, the government enacted the Chiefs and Headmen Act, which provided for a central role of the national government in the appointment and disciplining of traditions leaders. The Act also limited the role of traditional leaders in rural local governance. The 1992 Amendments to the Chiefs and Headmen Act did not significantly improve the status and role of traditional leaders.

Like its colonial predecessor, the ZANU-PF government had embarked on a deliberate policy to weaken the institution of traditional leadership. Traditional leaders were stripped of some of their powers because they were considered to have supported the exploitation of black Africans by collaborating with the colonial government. Although the reduction of the powers of traditional leaders was initially implemented 
as a form of retribution for their past collusion with the colonialists, it also signalled the intention of the post-independence government of promoting democratic governance at local level without traditional leaders (Makumbe, 1998: 33).

Four years after independence, the government through the prime minister issued a series of directives to promote decentralization and democratic participation. The directives came to be known as the Prime Minister's Directives on Decentralization and Development. In 1985, the Directives received legal recognition through the Provincial Councils and Administration Act [Chapter 29:11]. The directives aimed to democratize the local government system particularly in the communal areas of Zimbabwe which lacked 'genuine' representative local structures in the colonial era (Makumbe, 1998: 27). This included promoting bottom-up governance and coordination by providing for the establishment of a hierarchy of representative bodies at the village, ward, district and provincial levels. The directives perhaps brought about the most significant changes to the post-independence system of decentralized governance in Zimbabwe prior to the adoption of the 2013 Constitution. The role of traditional leaders received little if any recognition in the Directives. The stance continued when the Rural District Councils Act adopted in 1988 (which sought to regulate rural local government) did not provide for any significant role for traditional leaders. In 1996, the government adopted the "Thirteen Principles of Decentralization" as government policy to guide the decentralization of powers and functions to local governments, in particular, rural local governments. Again, the principles were silent on the role of traditional leaders.

The relegation of the institution of traditional leadership did not continue for long. As highlighted above, at independence, the administrative and judicial functions of traditional leaders had been transferred to district councils and community courts, respectively. In the 1980s and 1990s, traditional leaders continued to lobby the national government for the restoration of their powers. Although during this period traditional leaders had lost significant powers, they retained significant influence in rural areas, which created "operational anxieties" for rural local government structures and processes (Chatiza, 2010: 16). The question of how long the government was to continue relegating the institution of traditional leadership given the respect and support they commanded gained prominence. The support and cooperation of traditional leaders for effective policy implementation and development in rural areas was seen as vital. The combined effect of these two factors resulted in major policy shift towards traditional leaders in the late 1990s (See Obediah, 2013).

At this point it is important to note that Zimbabwean experience is not unique in the post-colonial politics in Africa. Similar patterns of change in government policy towards traditional authorities were taking place throughout Africa around that time. In neighbouring Mozambique, the Front for the Liberation of Mozambique (FRELIMO) led government had abolished the institution of traditional leadership in line with its democratization ideals soon after assuming power in 1975. But during the period of the civil war that followed, FRELIMO was forced to redefine its policy on traditional leadership by acknowledging that the institution of traditional leadership had a role to play in the lives of Mozambicans (Logan, 2008). A number of African countries including Burkina Faso, Guinea, Zambia, Guinea, Uganda and Tanzania had also attempted unsuccessfully to strip chiefs of most of their authority 
or even abolish chieftaincy altogether. But almost everywhere, in face of their enduring presence, post-colonial governments had to backtrack and find ways to use the traditional authorities to their advantage.

In Zimbabwe, the clearest sign of the government's positive attitude towards traditional leaders was reflected by the Traditional Leaders Act of 1998 [Chapter 29: 17]. For the first time in the post-colonial era, the Act recognized the institution of traditional leadership as an important governance structure in rural areas. It restored their powers to allocate rural land and to try civil and criminal cases in rural areas, among other local governance obligations. Besides the Act, the president issued a public apology for neglecting chiefs since independence as a way of reinventing the relationship between the government and traditional authorities (Ranger 2001 cited in Makahamadze et al., 2009: 43). The Traditional Leadership Act also provided for the establishment of the Council of Chiefs and Provincial Assemblies of Chiefs, platforms where the national government would consult with chiefs on issues affecting the institution of traditional leadership and inhabitants of communal areas. This was an important step in the formalization of the hitherto uncodified powers of traditional leaders, and in some cases, it seems to have brought them into national politics. Chief Svosve in Mashonaland East Province is generally regarded to have pioneered the land reoccupation process in the early 2000s which eventually led to the official land reform programme in Zimbabwe. It was after the people of Svosve Communal Area, upon the directive of their chief, forcefully occupied some prime agricultural land which belonged to white farmers in the province that the ZANU-PF led government began the fast-track land reform programme. The conduct of Chief Svosve resulted in a major policy shift from the "willing-buyer-willing-seller" approach which the government had adopted at independence to a compulsory acquisition of land without benefits approach. ${ }^{1}$

The government's positive attitude towards traditional leaders continued in the post-2000 era. The Traditional Leaders Act was amended in 2002 widening the role of traditional leaders. The amendments provided for the establishment of village and ward assemblies which were now to be composed of elected officials and traditional leaders. The assemblies are charged with facilitating participatory development and the general governance of areas within their jurisdictions, such as cultural and land matters. In a nutshell, the Traditional Leadership Act for the first time in the postindependence era recognized the dual importance of democratically based structures and traditional authority for rural governance.

In the first two decades of independence, the ZANU-PF led government had faced little opposition and commanded significant support. The government relegated traditional leaders more or less during this same period. From the year 2000 when the legitimacy of the government was beginning to be questioned and also when formidable opposition political party (Movement for Democratic Change) entered the political arena, the ZANU-PF led government has increasingly relied on traditional leaders for its survival. ZANU-PF has "sought the assistance of traditional leaders to influence both electoral and governance processes" (Chakaipa, 2010: 53; Makumbe, 2010: 88, 93-94). The ZANU-PF led government has sponsored the purchase of cars and construction of modern houses, with electricity and water, for chiefs (See Makahamadze et al., 2009; Obediah, 2013). Although it is stated that the allocation of cars and 
construction of houses was to improve the well-being of chiefs, Chakaipa (2010) and Makumbe (2010) claim that the real objective is to entice chiefs to organize support for the government and, in particular, ZANU-PF. At the moment, most traditional leaders in Zimbabwe lend support to the ruling government for fear of losing their positions, benefits and privileges as well as the threat of victimization (see Makahamadze et al., 2009). Makumbe (2010: 88, 93-94) claims that chiefs have made it extremely difficult for opposition political parties to mobilize political support in rural areas by threatening and punishing people who are seen to sympathize with political parties other than ZANU-PF. Obediah (2013) lists these areas as including Mutoko, Uzumba-MarambaPfungwe, Muzarabani, Buhera and Hurungwe. Those few chiefs who have refused to actively mobilize political support for ZANU-PF or allowed opposition political parties to organize politically in their areas have been victimized by state agencies and threatened with withdrawal of government support (Makahamadze et al., 2009; Makumbe, 2010: 94). Thus, the argument that "the institution of traditional leadership in Zimbabwe, [like elsewhere in Africa], has gone through colonial and post-colonial acceptance, usage and political corruption" may be appropriate (Chatiza 2010: 17). Traditional leaders collaborated with successive colonial governments and helped control the black population in communal areas. They have also allowed themselves to be used by the ZANU-PF government for partisan politics.

As political uncertainty looms on the horizon, despite all these shortcomings, traditional authorities will have to be called on to play a key role as outlets for grassroots democracy in rural areas. Politics may very soon change in Zimbabwe. So it will be important to remember that everything else comes and goes, but traditional authorities remain. So this time around, they should not be seen as arms of the centre in controlling the population, but as home-grown institutions with deep roots that can potentially be reformed to act as the democratic voice of rural Zimbabwe.

\section{Acknowledgements}

The author is grateful to Jan Erk who played an instrumental role in the drafting of this article.

\section{Disclosure Statement}

No potential conflict of interest was reported by the author.

\section{Note}

${ }^{1}$ It should be noted however that the new approach or policy, while intended to promote equity in ownership of prime agricultural land, has had major adverse repercussions on the political and economic well-being of Zimbabwe since its adoption in the early 2000s.

\section{References}

Andrew, C. and Goldsmith M. (1998), From local government to local governance: And beyond? International Political Science Review, New Trends in Municipal Governance, Vol.19, No.2, pp.101-117. 
Bardhan, P. and Mookherjee D. (2006), The rise of local governments: An overview, in P. Bardhan and D. Mookherjee (eds), Decentralisation and Local Governance in Developing Countries, pp. 1-52. Massachusetts: Massachusetts Institute of Technology.

Bates, R. (1981), Markets and States in Tropical Africa: The Political Basis of Agricultural Policies. Berkeley: Berkeley University Press.

Bratton, M. and Chang, E.C.C. (2006), State-building and democratization in Africa: Forwards, backwards, or together? Comparative Political Studies, Vol.39, No.9, pp. 1059-1083.

Chakaipa, S. (2010), Local government institutions and elections, in J. De Visser, N. Steytler and N. Machingauta (eds), Local Government in Zimbabwe: A Policy Dialogue, pp.31-68. Bellville: Community Law Centre, University of the Western Cape.

Chatiza, K. (2010), Can local government steer socio-economic transformation in Zimbabwe? Analysing Historical trends and gazing the future, in J. De Visser, N. Steytler and N. Machingauta (eds), Local Government in Zimbabwe: A Policy Dialogue, pp.1-25. Bellville: Community Law Centre, University of the Western Cape.

Crowder, M. (1964), Indirect rule, French and British styles, Africa, Vol.33, No.4, pp. 293-306.

De Valk, P. and Wekwete, H.K. (1990), Challenges for Local Government in Zimbabwe, in H.K. Wekwete and P. De Valk (eds), Decentralisation for Participatory Planning, pp.86-98. Avebury: Aldershot Gower Publishing Company.

De Visser, J. (2005), Developmental Local Government: A Case Study of South Africa. Intersentia: Antwerpen-Oxford.

Erk, J. (2014), Federalism and decentralization in Sub-Saharan Africa: Five patterns of evolution, Regional and Federal Studies, Vol.24, No.5, pp.535-552.

Erk, J. (2015), Iron houses in the tropical heat: Decentralization reforms in Africa and their consequences, Regional and Federal Studies, Vol.25, No.5. doi:10.1080/13597566.2015.1114921.

Fessha, Y. and Kirkby, C. (2008), A critical survey of subnational autonomy in African states, Publius, Vol.38, No.2, pp.248-271.

Jackson, P. and Scott, Z. (2008), Local Government in Post-Conflict Environments, Paper presented at the workshop on Local Government in Post-Conflict Situations: Challenges for Improving Local Decision-making and Service Delivery Capacities, UNDP, Bureau for Development Policy, Democratic Governance Group, Oslo Governance Centre, 28-29 November 2007.

Jordan, D.J. (1983), Local Government in Zimbabwe: An Overview. Harare: Mambo Press.

Keulder, C. (1998), Traditional Leaders and Local Government in Africa: Lessons for South Africa. Pretoria: Human Sciences Research Council.

Krol, G. (2015), Policy decentralization and the endogenous effects of state traditions: Devolution of water management in Ghana and Senegal, Regional and Federal Studies, Vol.25, No.5. doi:10.1080/ 13597566.2015.1114922.

Logan, C. (2008), Traditional Leaders in Modern Africa: Can Democracy and the Chief Co-exist? Afrobarometer Working Paper No. 93, Michigan State University (Michigan), the Institute for Democracy in South Africa (Pretoria) and the Centre for Democratic Development (Ghana).

Makahamadze, T., Grand, N. and Tavuyanago, B. (2009), The role of traditional leaders in fostering democracy, justice and human rights in Zimbabwe. The African Anthropologists, Vol.16, No.1 and 2, pp.33-47.

Makumbe, J. (1998), Democracy and Development in Zimbabwe: Constraints on Decentralisation. Harare: Southern African Political Economy Series.

Makumbe, J. (2010), Local authorities and traditional leadership, in J. De Visser, N. Steytler and N. Machingauta (eds), Local Government in Zimbabwe: A Policy Dialogue, pp.87-99. Bellville: Community Law Centre, University of the Western Cape.

Marsh, E.G., Roper, E.D. and Kotze, D.A. (1974), Local government in Rhodesia, in W.B. Vosloo, A.D. Kotze and O.J.W. Jeppe (eds), Local Government in Southern Africa, pp.183-230. Cape Town: H and R Academia.

Musekiwa, N. (2012), The role of local authorities in democratic transition, in E. Masunungure and J. Sumba (eds), Democratic transition, pp.230-251. Harare: Weaver Press and IDAZIM.

Mutizwa-Mangiza, N.D. (1991), Decentralization and local government in Zimbabwe: An analysis of structural and planning problems at the rural district levels, in A.H.J. Zimbabwe Helsming, N. Mutizwa- 
Mangiza, D. Gasper, C. Brand and K. Wekwete (eds), Limits to Decentralisation: Essays on the Decentralisation of Government and Planning in the 1980s. pp.51-78. The Hague: Institute of Social Studies.

Obediah, D. (2013), Traditional leadership systems and gender recognition: Zimbabwe, International Journal of Gender and Women's Studies, Vol.1, No.1, pp.29-44.

Palley, C. (1966), The Constitutional History and Law of Southern Rhodesia (1888-1965): With Special Reference to Imperial Control. Oxford: Clarendon Press.

Pandey, S. (2005), Democracy and Decentralisation, available at SSRN. Available at http://ssrn.com/ abstract=878432 or http://dx.doi.org/10.2139/ssrn.878432 (accessed 14 February 2012).

Rambanapasi, O. (1992), Decentralization and recentralisation in the historical development of the local government system of Zimbabwe, International Journal of Public Administration, Vol.15, No.8, pp. $1493-1525$.

Siegle, J. and O'Mahony, P. (2010), Decentralization and internal conflict, in E. Connerley, K. Eaton and P. Smoke (eds), Making Decentralisation Work, pp.135-166. London: Lynne Rienner Publishers.

UNECA (United Nations Economic Commission for Africa), Development Policy and Management Division (2004), Relevance of African Traditional Institutions of Governance, Paper prepared by Busia Kojo, Oertel Stephane and Mengesha Hasna. Available at http://repository.uneca.org/bitstream/ handle/10855/3086/bib.\%2025702_I.pdf?sequence=1 (accessed 27 September 2015).

Zimstat (Zimbabwe National Statistics Agency). Zimbabwe Population Census 2012, National Report, Harare: Zimstat. 
